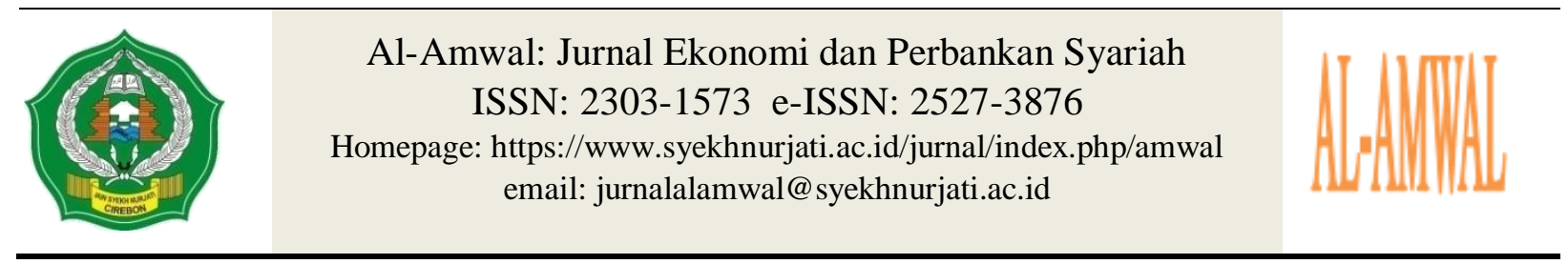

\title{
POLITICAL CONNECTION AND TAX AVOIDANCE ON SHARIA STOCKS: GOOD FOR BUSINESS?
}

\author{
Fadlil Abdani \\ UIN Maulana Malik Ibrahim Malang \\ e-mail: fadlilabdani@uin-malang.ac.id \\ Annisa Fitri Sya'bania \\ Universitas Airlangga \\ e-mail: annisa.fitri.s@vokasi.unair.ac.id
}

\begin{abstract}
This research is used to determine the influence of political connections on tax avoidance. Researchers use government ownership and directors and commissioners who hold multiple positions as former government officials and military officials to measure variable political connections. Tax avoidance is measured using cash effective tax rate (CETR). The data in this study used secondary data in annual reports on companies included in the Jakarta Islamic Index period 2015-2018. The method used in this study is quantitative analysis, and the results show that political connections through government ownership affect tax avoidance; the same is also evident in political connections through BOD profiles and BOC profiles affecting tax avoidance.
\end{abstract}

Keywords: Tax Avoidance, Political Connection, Sharia Stock

\begin{abstract}
Abstrak
Penelitian ini digunakan untuk mengetahui pengaruh koneksi politik terhadap tax avoidance. Peneliti menggunakan kepemilikan pemerintah dan direksi maupun komisaris yang merupakan rangkap jabatan sebagai ataupun mantan pejabat pemerintahan, pejabat militer untuk mengukur variabel koneksi politik. Tax avoidance diukur menggunakan cash effective tax rate (CETR). Data pada penelitian ini menggunakan data sekunder berupa annual report pada perusahaan yang termasuk dalam Jakarta Islamic Index periode 2015-2018. Metode yang digunakan dalam penelitian ini adalah analisis kuantitatif, dan hasil penelitian menunjukkan bahwa koneksi politik melalui kepemilikan pemerintahan berpengaruh terhadap tax avoidance, hal yang sama juga terbukti pada koneksi politik melalui profil BOD dan profil BOC berpengaruh terhadap tax avoidance.
\end{abstract}

Kata kunci: Tax Avoidance, Koneksi Politik, Saham Syariah 


\section{INTRODUCTION}

In developing and developed countries, economic growth impacts the imposition of taxes and tax revenues in a Country (Davoodi \& Zou, 1998). Ardani (2010) added that it should have been included, or tax receipts could be stable if not affected by changes in the global economy. This has made the Indonesian government more active in increasing its primary revenue in terms of tax receipts. This also makes the Indonesian government continue to push for improvements in the tax sector, among others, in 1983 there were changes to the tax system from the official assessment system to the self assessment system (Devano \& Wato, 2006).

The change of the system to self assessment system did not have a good improvement, but the reality of the proportion of tax receipts to the state budget increased in the last five years, since 2015 - 2019 shows an increase of $73 \%$ in 2015 to $84 \%$ in 2019 . The increase cannot yet represent that all potential taxation is maximal, because many still do not care about the importance of fulfilling the tax obligations of both corporate taxpayers and private tax payers. In the period $2015-2019$ also shows that tax receipts did show an increase, but have not met the target.

The achievement of the State revenue target through this tax is influenced by various factors, one of which is the practice of tax avoidance. Mardiasmo (2011) explained that there are actions done deliberately to avoid tax, namely tax avoidance and tax evasion. Tax avoidance is an attempt to reduce taxes paid to the State without violating any tax laws or regulations. In contrast, Tax evasion is an attempt to alleviate taxes paid to the State in violation of regulations or laws.

In Corporate Taxpayers, for example, companies make efforts to minimize the cost of paying taxes without violating tax rules. This is done because of the more significant the Company's profit, the greater the tax that must be deposited to the State. Wicaksono (2017) said to achieve the goal of paying taxes efficiently and not to violate regulations, one of them by doing proper tax planning. This goal can be achieved one of them by doing tax avoidance, which is one way of tax planning to manage its profit or income in order to minimize the tax that must be deposited; the effort is legitimate even though it reduces the State's receipts, but can not be penalized for not violating regulations and being in the grey area (Zain, 2008). Maharani \& Suardana (2014) argue that tax avoidance is unique because it is a legitimate and often done company, but is not desirable by the government because it reduces receipts.

The practices used as the use of weaknesses in tax regulation do not violate the tax code, so it is legal to do so.Hanlon \& Heitzman (2010) explains that in the context of tax compliance, a person is affected by factors including tax rates, sanctions or fines, and tax evasion.Prebble \& Prebble (2009) argued that the initial nature of tax avoidance was not biased in sanctioning the Company directly, but sanctions could be imposed if there were laws governing restrictions on the use of tax avoidance.

Several studies have been conducted to study tax avoidance, such as research conducted byDyreng et al. (2010) and Budiman (2012) which measures tac avoidance with CETR (Cash Effective Tax Rate) by dividing Cash tax paid with Pretax income. Besides, some studies mention that tax avoidance is also influenced by other factors, namely the size of the Company and the character of the executive(Pranoto \& Widagdo, 2016). Another factor being considered in tax avoidance is political connections or 
proximity to the government.Zhang et al.(2012) mention that companies that have ties to the government and have political connections show lower tax avoidance than companies with no relationship with the government.

The preparation of the Company's strategy to compete with competitors should utilize all potentials, including political connections or good relations with the government (Leuz \& Gee, 2006). Faccio (2006) added that every Company wants a good relationship with the government to get preferential treatment, primarily if a government official owns the Company or there are government officials who have a particular position in the Company. It is also made clear by Faccio (2006) that a limited company is said to have political connections if there is one major shareholder or one of the leaders in the Company, whether the CEO, president director or has a relationship with a political even if one of its leaders is a member of a political.

Political connections are also useful in minimizing the cost of taxes to be deposited and corporate access to dealing with the central government (Kim \& Zhang, 2016). Many developing countries have companies with political connections, such as having proximity to the government, so that officials or members of politicalies have positions as commissioners and directors (Fisman, 2001). As is the case in Indonesia, there are many government-related companies, from the shareholding structure to government officials' placement in certain positions in the Company. This attracted researchers to research political connections and tax avoidance with a sample of companies recorded in the Jakarta Islamic Index.

\section{LITERATURE REVIEW}

\section{Agency Theory}

Large companies are supposed to separate wealth between the owner and the Company, this is done so that the owner gives the authority to manage the Company, including taking strategic decisions. The agency theory explains the relationship between the owner of the Company and the management or manager of the Company. Jensen (1986) explained that the principal would authorize the agent to manage his property, both parties bound by a contract of employment consisting of their respective rights and obligations.

Agency theory is relevant to this research related to the difference of authority between the Company and the government in terms of tax receipts and tax payments made by the Company. The government, considered the Company's principal owner, wants the maximum tax revenue possible, while the Company's management wants a high profit without having to pay high taxes anyway. This is the point of difference and creates a conflict of interest.

\section{Tax Avoidance}

Tax avoidance is an activity used to transfer resources that should be paid to the State to shareholders to generate higher returns (Butje \& Tjondro, 2014). The explanation is provided by Zain (2008) that tax avoidance is part of tax planning carried out through profit management, to minimize taxes paid to the State without violating tax regulations. 
Tax avoidance does not include unlawful acts, but actions that take advantage of tax regulation opportunities in a State. The act of reducing this tax liability without violating the rules can be considered lawful. The nature of tax avoidance is also not to blame and is punishable or punished. EvenPrebble \& Prebble (2009) explained that sanctions could have been imposed if there were laws governing limits on tax avoidance.

Tax avoidance can be measured by several formulas, namely Effective Tax Rate (ETR), Cash Effective Tax rate (CETR), and Book Tax Differences (BTD). Here are some measurement categories of tax avoidance;

Effective Tax rate (ETR) is a measurement considered to show the difference between book profit and fiscal profit. Besides, ETR also sees the tax expense paid in the current year (Utami \& Setyawan, 2015) the formula as follows;

$\mathrm{ETR}=\frac{\text { Tax Expense }}{\text { Pretax Income }}$

Cash Effective Tax Rate (CETR) is a measurement seen based on the comparison of the amount of tax paid with pretax profit(Rusydi \& Martani, 2014) formulated as follows;

Cash ETR $=\frac{\text { Cash Tax Paid }}{\text { Pretax Income }}$

Book Tax Differences (BTD) is the difference between accounting profit and fiscal profit judging by temporary differences and indicated by deferred tax expense account (Rusydi \& Martani, 2014) formulated as follows;

$\mathrm{BTD}=\frac{\text { Total Difference Book }- \text { Tax }}{\text { Total Aset }}$

\section{Political Connections}

The Company can be said to have political connections if one of the major shareholders or one of the Company's leaders, whether the CEO, board of directors, or commissioner, is a member of parliament, minister, or who has a special relationship with the government or political(Faccio, 2006).Gomez(2009) also added that companies with unique relationships with the government belong to companies that make political connections. Special relationship means as one of the government-owned companies, either in the form of BUMN orBUMD.

Some companies want to have a special relationship with the government or political to have a lower detection risk because politicians are considered to protect the Company in terms of its taxation. Furthermore, the Company may also get the latest information on changes to tax regulations in the future. 


\section{Hypothesis Development}

Wicaksono (2017) stated that political connections have a positive impact and negative impact on tax avoidance. The positive impact of the Company getting preferential treatment from the government related to its tax aspects, tax avoidance checks and others. Meanwhile, the negative impact in the form of State revenue is reduced due to tax avoidance carried out by the Company. Zhang et al. (2012) showed that political connections have an effect on tax aggressiveness, which Fisman (2001) also pointed out that political connections often occur in developing countries, where there are parties placed in the organizational structure of companies, of course, that have a special relationship with the government. Based on the study, the first hypothesis taken was;

\section{$\mathrm{H}_{1}$ : Political connections affect tax avoidance}

Aside from some of the research mentioned above, other things affect tax avoidance, such as BOC and BOD profiles in a company. Lestari \& Putri (2017) concluded that corporate governance, political connections, and leverage have a simultaneous tax avoidance effect.Butje \& Tjondro (2014) also mentioned that executive character and political connections have a significant effect on tax avoidance, while variable control in the form of company size, leverage, and sales growth also has a significant positive effect on tax avoidance. Therefore from the study, the second hypothesis is taken;

$\mathrm{H}_{2}$ : BOC and BOD profiles affect tax avoidance

\section{METHOD}

\section{Type of research}

This research uses quantitative methods, which are approaches that look at a reality that can be clarified, observed, measured, and causal between variables (Sugiyono, 2010). The research was conducted on companies included in the Jakarta Islamic Index period 2015-2018, with the criteria fixed in each announcement of a list of securities including sharia stocks.

\section{Variable Operational Definition}

The independent variables used in this study are political connections. The Company can be said to have political connections if one of the major shareholders or one of the Company's leaders, whether the CEO, board of directors, or commissioner, is a member of parliament, minister, or who has a special relationship with the government or political (Faccio, 2006). Gomez (2009) also added that companies with unique relationships with the government belong to companies that make political connections. Political connection variables are measured using dummy variables, which are given a value of 1 for companies that meet one of the criteria of political connections and are given a value of 0 if they do not meet the political connection criteria. Among the criteria for political connections are; 1) The Board of Directors or Board of Commissioners concurrently politicians; 2) The Board of Directors or Board of Commissioners concurrently as a government official; 3) The Board of Directors or 
Board of Commissioners concurrently positions as military officers; 4) The owner of the Company or shareholder is a member of a political, government official, military official, former government official or former military official (Utari \& Supadmi, 2017).

The dependent variable in this study was tax avoidance. Activity is used to transfer resources that should be paid to the State to shareholders generates higher returns (Butje \& Tjondro, 2014). The explanation is provided byZain(2008) that tax avoidance is part of tax planning carried out through profit management, to minimize taxes paid to the State without violating tax regulations. The measurement used in this study is CETR. Cash Effective Tax Rate (CETR) is a measurement seen based on the comparison of the amount of tax paid with pretax profit(Rusydi \& Martani, 2014) formulated as follows;

$$
\text { Cash ETR }=\frac{\text { Cash Tax Paid }}{\text { Pretax Income }}
$$

\section{Data Analysis}

The data to be processed in this study uses multiple linear regression models. Regression methods can be used to show how independent variables affect dependent variables (Ghozali, 2006). Multiple linear regression equations can be seen as follows:

$$
\text { CETR }=\propto+b 1 \text { Polcon } 1+b 2 \text { Polcon } 2+\varepsilon
$$

Description:

CETR = Cash Effective Tax Rate

POLCON1 = Political connections through shareholdings

POLCON2 = Political connections through BOC \& BOD

\section{RESULT AND DISCUSSION}

One way to see normality is to look at the results of the Kolmogorov-Smirnov test. Normality test results can be seen as follows:

Table 1

One-Sample Kolmogorov-Smirnov Test

\begin{tabular}{lrr}
\hline \multicolumn{1}{c}{ Model } & $\begin{array}{c}\text { Unstandardized } \\
\text { Residual }\end{array}$ \\
\hline $\mathbf{N}$ & & 88 \\
Normal Parameters & Mean & $0 \mathrm{E}-7$ \\
& Std. Deviation & 21.67719443 \\
Most Extreme Differences & Absolute & .133 \\
& Positive & .133 \\
Kolmogorov-Smirnov Z & Negative & -.077 \\
Asymp. Sig. (2-tailed) & & 1.249 \\
\hline Source: Data Processing & & .088 \\
\hline
\end{tabular}

Source: Data Processing

Based on table 1, it appears that the value of Kolmogorov-Smirnov Z of 1,249 with a significant rate of 0.088 means that the distributed research variable is normal 
due to its signification rate $\geq 0.05$, so that tax avoidance and political connections are distributed normally. Besides, the next stage is to test the top multicholiners conducted to test whether there is a correlation between independent variables in the regression model. Statistical identification of the existing or not multicollinearity symptoms can be made by determining the Variance Inflation Factor (VIF) and Tolerance Value (TOL).

Table 2

Tolerance and VIF

\begin{tabular}{|c|c|c|c|c|c|c|c|}
\hline \multirow[t]{2}{*}{ Model } & \multicolumn{2}{|c|}{$\begin{array}{c}\text { Unstandardized } \\
\text { Coefficients } \\
\end{array}$} & \multirow{2}{*}{$\begin{array}{c}\begin{array}{c}\text { Standardized } \\
\text { Coefficients }\end{array} \\
\text { Beta }\end{array}$} & \multirow[t]{2}{*}{$\mathbf{t}$} & \multirow[t]{2}{*}{ Sig. } & \multicolumn{2}{|c|}{ Collinearity Statistics } \\
\hline & $\mathrm{B}$ & Std. Error & & & & Tolerance & VIF \\
\hline Constant & 40.042 & 3.515 & & 11.391 & .000 & & \\
\hline Polcon 1 & 16.348 & 6.041 & .334 & 2.706 & .008 & .704 & 1.420 \\
\hline Polcon 2 & -12.982 & 5.608 & -.286 & -2.315 & .023 & .704 & 1.420 \\
\hline
\end{tabular}

Based on table 2 obtained results that all variables are free of tolerance values above 0.10 and VIF values are smaller than 10, meaning that all free variables in this study have no symptoms of multicollinearity with the rule if $\mathrm{VIF}<10$ and tolerance value $>0.10$, then there are no symptoms of multicollinearity (Ghozali, 2006).

The next stage of the autocorrelation test aims to test whether there is a correlation between disruptive errors in the $t$ period and undue errors in the previous period (Ghozali, 2006). To detect the absence of autocorrelation judging by Durbin Watson value.

Tabel 3

Summary

\begin{tabular}{cccccc}
\hline Model & R & R Square & $\begin{array}{c}\text { Adjusted R } \\
\text { Square }\end{array}$ & $\begin{array}{c}\text { Std. Error of the } \\
\text { Estimate }\end{array}$ & $\begin{array}{c}\text { Durbin- } \\
\text { Watson }\end{array}$ \\
\hline $\mathbf{1}$ & .299 & .089 & .068 & 21.93074 & 1.722 \\
\hline Source: Data Processing & & & & &
\end{tabular}

Based on table 3, it can be noted that the autocorrelation test results show a DW value of 1,722 more than the DU value of 1,699; hence no autocorrelation (Ghozali, 2006). Similarly, the calculation results on the hypothesis test are as follows:

Tabel 4

\section{Coefficients}

\begin{tabular}{|c|c|c|c|c|c|}
\hline \multirow{2}{*}{ Model } & \multicolumn{2}{|c|}{$\begin{array}{l}\text { Unstandardized } \\
\text { Coefficients }\end{array}$} & \multirow{2}{*}{$\begin{array}{c}\text { Standardized } \\
\text { Coefficients } \\
\text { Beta }\end{array}$} & \multirow{2}{*}{$\mathrm{T}$} & \multirow{2}{*}{ Sig. } \\
\hline & B & Std. Error & & & \\
\hline Constant & 40.042 & 3.515 & & 11.391 & .000 \\
\hline Polcon 1 & 16.348 & 6.041 & .334 & 2.706 & .008 \\
\hline Polcon 2 & -12.982 & 5.608 & -.286 & -2.315 & .023 \\
\hline
\end{tabular}


Based on the calculation results presented in table 4, showing a significance value of 0.008 , which means the value of significance is smaller than 0.05 , then $\mathrm{H} 0$ is successfully rejected, and hypothesis 1 is supported. So it can be concluded that political connections through shareholding affect tax avoidance. The results of this study also show that political connections positively impact getting preferential treatment from the government regarding aspects of taxation. This research also supportsZhang et al. (2012) finding that political connections affect tax aggressiveness. As well asFisman (2001) pointed out states that political connections often occur in developing countries, where there are parties placed in the company's organizational structure, of course, who have a special relationship with the government. The same findings also relate toKim \& Zhang's (2016) research on political connections impacting the government's preferential treatment in terms of taxation, such as avoiding tax checks.

The second hypothesis test showed a significance value of 0.023 , which means the value of significance is smaller than 0.05 , then $\mathrm{H} 0$ is successfully rejected, and hypothesis 2 is supported. So it can be concluded that political connections through the board of commissioners' profile and the board of directors affect tax avoidance. The results of this study also support what Wicaksono (2017) says profiles of the board of commissioners and the board of directors originating from political parties, government officials, and military officials influential on tax avoidance. What Utari \& Supadmi (2017) and Butje \& Tjondro (2014) stated how independent commissioners and audit committees' existence affect tax avoidance is also relevant to this research. Companies that feel privileged by the government tend to commit tax evasion because they feel protected and will not be examined in detail by the tax authorities.

Researchers found that some companies have military connections. This is evidenced by former military officials who have certain positions such as being one of the board of commissioners. Similarly, former government officials were also found to have served as commissioners at one of the Jakarta Islamic Index list companies. The criteria of companies listed in the Jakarta Islamic Index are only the 30 most liquid sharia stocks with the review process twice a year. This should also be a filter that the sharia stocks that enter are viable and most liquid. It is also seen from the highest average market capitalization for a year and has the highest average value of daily transactions in the stock market. It should be that sharia stocks listed in the Jakarta Islamic Index are an example of taxpayers who are compliant with other companies on the stock exchange.

\section{CONCLUSION}

The research was conducted to test the influence of political connections through shareholdings and the board of commissioners' profile and the board of directors on tax avoidance. Political connection variables are measured using dummy variables, where the political connection criteria are; 1) The Board of Directors or Board of Commissioners concurrently politicians; 2) The Board of Directors or Board of Commissioners concurrently as a government official; 3) The Board of Directors or Board of Commissioners concurrently positions as military officers; 4) The owner of the company or shareholder is a member of a political party, government official, 
military official, former government official or former military official (Utari \& Supadmi, 2017). In comparison, tax avoidance is measured by Cash Effective Tax Rate (CETR), a measurement seen based on the comparison of the amount of tax paid with profit before tax (Rusydi \& Martani, 2014).

The results showed that political connections through shareholdings and the board of commissioners' profile and board of directors influenced tax avoidance. This means companies that feel privileged by the government tend to commit tax avoidance because they feel protected and will not be examined in detail by the tax authorities. This study's results have implications for the company can be used as an additional insight so that the management of the company can do tax planning well and not violate tax regulations that can harm the State despite having political connections. The results of this study also have implications for subsequent researchers in tax avoidance and political connections.

\section{REFERENCES}

Ardani, M. N. (2010). "Pengaruh Kebijakan Sunset Policy Terhadap Kepatuhan Wajib Pajak (Sudi Kasus di Kanwil Direktorat Jenderal Pajak Jawa Timur I Surabaya)”. [PhD Thesis]. Universitas Diponegoro.

Budiman, J. (2012). Pengaruh Karakter Eksekutif terhadap Penghindaran Pajak (Tax Avoidance) [PhD Thesis]. [Yogyakarta]: Universitas Gadjah Mada.

Butje, S., \& Tjondro, E. (2014). Pengaruh Karakter Eksekutif dan Koneksi Politik Terhadap Tax Avoidance. Tax \& Accounting Review, 4(2).

Davoodi, H., \& Zou, H. (1998). Fiscal decentralization and economic growth: A crosscountry study. Journal of Urban Economics, 43(2), 244-257.

Devano, S., \& Wato, T. (2006). Pengaruh Pemeriksaan Pajak Terhadap Penerimaan Pajak (Studi Kasus: Di KPP Jakarta Kebon Jeruk). Jurnal Keuangan Publik, 4(2).

Dyreng, S. D., Hanlon, M., \& Maydew, E. L. (2010). The effects of executives on corporate tax avoidance. The Accounting Review, 85(4), 1163-1189.

Faccio, M. (2006). Politically connected firms. American Economic Review, 96(1), $369-386$.

Fisman, R. (2001). Estimating the value of political connections. American Economic Review, 91(4), 1095-1102.

Ghozali, I. (2006). Aplikasi analisis multivariate dengan program SPSS. Badan Penerbit Universitas Diponegoro.

Gomez, E. T. (2009). The rise and fall of capital: Corporate Malaysia in historical perspective. Journal of Contemporary Asia, 39(3), 345-381.

Hanlon, M., \& Heitzman, S. (2010). A review of tax research. Journal of Accounting and Economics, 50(2-3), 127-178.

Jensen, M. C. (1986). Agency costs of free cash flow, corporate finance, and takeovers. The American Economic Review, 76(2), 323-329.

Kim, C., \& Zhang, L. (2016). Corporate political connections and tax aggressiveness. Contemporary Accounting Research, 33(1), 78-114.

Lestari, G. A. W., \& Putri, I. A. D. (2017). Pengaruh corporate governance, koneksi politik, dan leverage terhadap penghindaran pajak. E-Jurnal Akuntansi Universitas Udayana, 18(3), 2028-2054. 
Leuz, C., \& Gee, F. O. (2006). Political relationships, global financing, and corporate transparency: Evidence from Indonesia. Journal of Financial Economics, 81(2), 411-439.

Maharani, I., \& Suardana, K. A. (2014). Pengaruh corporate governance, profitabilitas dan karakteristik eksekutif pada tax avoidance perusahaan manufaktur. E-Jurnal Akuntansi Universitas Udayana, 9(2), 525-539.

Mardiasmo. (2011). Perpajakan Edisi Revisi (11th ed.). Yogyakarta: Andi Offset.

Pranoto, B. A., \& Widagdo, A. K. (2016). Pengaruh Koneksi Politik dan Corporate Governance Terhadap Tax Aggressiveness.

Prebble, Z., \& Prebble, J. (2009). The morality of tax avoidance. Creighton L. Rev., 43, 693.

Rusydi, M. K., \& Martani, D. (2014). Pengaruh Struktur Kepemilikan terhadap Aggressive Tax Avoidance. Simposium Nasional Akuntansi XVII, 24-27.

Sugiyono, P. D. (2010). Metode penelitian pendidikan. Pendekatan Kuantitatif.

Utami, W. T., \& Setyawan, H. (2015). Pengaruh Kepemilikan Keluarga terhadap Tindakan Pajak Agresif dengan Corporate Governance sebagai Variabel Moderating (Studi Empiris pada Perusahaan Manufaktur yang Terdaftar di Bursa Efek Indonesia Tahun 2010-2013). Conference In Business, Accounting, And Management (CBAM), 2(1), 413-421.

Utari, N. K. Y., \& Supadmi, N. L. (2017). Pengaruh Corporate Governance, Profitabilitas Dan Koneksi Politik Pada Tax Avoidance. E-Jurnal Akuntansi Universitas Udayana, 18(2).

Wicaksono, A. P. N. (2017). Koneksi politik dan aggresivitas pajak: Fenomena di indonesia. Jurnal Ilmu Akuntansi, 10(1), 167-180.

Zain, M. (2008). Manajemen Perpajakan. Salemba Empat.

Zhang, H., Li, W., \& Jian, M. (2012). How does state ownership affect tax avoidance? Evidence from China. Singapore Management University, School of Accountancy, 13-18. 